\title{
Novel Covid-19: The Surge in Plastics (Known-Unknowns), Its Impacts on Public and Environmental Health and The Way Forward
}

\author{
Ombugadu $\mathrm{A}^{1 *}$, Tanko $\mathrm{NS}^{2}$, Echor $\mathrm{BO}^{3}$, Abbas $\mathrm{AA}^{4}$, Namo JA ${ }^{5}$, Deme $\mathrm{GG}^{6}$, Ahmed $\mathrm{HO}^{1}$, Angbalaga \\ $\mathrm{GA}^{7}$, Atabo $\mathrm{EJ}^{8}$, Njila $\mathrm{HL}^{3}$, Aimankhu $\mathrm{OP}^{1}$, Samuel $\mathrm{MD}^{1}$, Attah $\mathrm{SA}^{1}$, Akpason $\mathrm{EA}^{7}$ and Micah EM ${ }^{1}$ \\ ${ }^{1}$ Department of Zoology, Faculty of Science, Federal University of Lafia, Lafia, Nasarawa State, Nigeria. \\ ${ }^{2}$ Department of Chemistry, Faculty of Science, Federal University of Lafia, Lafia, Nasarawa State, Nigeria. \\ ${ }^{3}$ Department of Science Laboratory Technology, Faculty of Natural Sciences, University of Jos, Plateau State, Nigeria
}

${ }^{4}$ Department of Clinical Laboratory, Institute of Human Virology Nigeria, Pent House, Maina Court, Plot 252 Herbert Macaulay Way, Central Business District, Abuja.

${ }^{5}$ Department of Urban and Regional Planning, Faculty of Environmental Sciences, University of Jos, Plateau State, Nigeria.

${ }^{6}$ State Key Laboratory of Ecology and Conservation, Institute of Zoology, Chinese Academy of Science, Beijing 100101, PR China.

${ }^{7}$ Department of Microbiology, Faculty of Science, Federal of University Lafia, Lafia, Nasarawa State, Nigeria.

${ }^{8}$ Nnamdi Azikiwe University Teaching Hospital, Nnewi, Anambra State, Nigeria.

*Corresponding author: Ombugadu A, Department of Zoology, Faculty of Science, Federal University of Lafia, Nasarawa

State, Nigeria, E-mail: akwash24@gmail.com

\section{ARTICLE INFO}

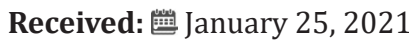

Published: 㗀 February 04, 2021

Citation: Ombugadu A, Tanko NS, Echor BO, Abbas AA, Namo JA, et al. Novel Covid-19: The Surge in Plastics (KnownUnknowns), Its Impacts on Public and Environmental Health and The Way Forward. Biomed J Sci \& Tech Res 33(4)2021. BJSTR. MS.ID.005437.

Abbreviations: PPE: Personal Protective Equipment; PET: Polyethylene Terephthalate; PP: Polypropylene; LDPE: Low Density Polyethylene; HDPE: High Density Polyethylene; PS: Polystyrene; EPS: Expanded Polystyrene; PVC: Polyvinyl Chloride; PLA: Polylactic Acid; PHA: Polyhydroxy Alkenoates; UF: Urea Formaldehyde; PVC: Polyvinyl Chloride; NBR: Nitrile Butadiene Rubber; CAGR: Compound Annual Growth Rate; PWF: Plastic Waste Footprints; MPs: Microplastics; OBRC: Oregon Beverage Recycling Cooperative; BAU: Business-asUsual; SCS: System Change Scenario; ROV:

\section{ABSTRACT}

Dreaded realities await us each day as we wake up due to the impact of anthropogenic activities. Coronavirus disease 2019 (COVID-19) has etched itself into every aspect of our lives, changing the way we behave and creating new normal. Our consumption habit has been unsustainable even before coronavirus hit. COVID-19 has just made a bad situation much worse. Since news of the coronavirus was first announced in January, its horrors have not stopped. The number of cases worldwide is still rising, and its death toll is appallingly high. Lockdowns was introduced in order to curb transmission of COVID-19 in which both e-commerce and health sectors resolved to using plastics ('known unknowns'). There is no denying that single-use plastic has been a lifesaver in the fight against COVID-19, especially for frontline health workers. It has also facilitated adherence to social-distancing rules, by enabling home delivery of basic goods, especially food. And it may have helped to curb transmission, by replacing reusable coffee cups and shopping bags in many cities over fears that the virus could stick to them. Though other studies have shown that SARS-COV-2 still last longer on single-use plastics (72 hours) than on cardboard (24 hours) and yet the paper industry association is not using this as an opportunity to lobby or directly profit from the crisis in comparison to the plastic industry association appealing for reversal on the ban of single-use plastics. Plastic pollution impacts behind the scenes on public and environmental health have both short- and longterm effects. Plastic-to-Ocean movement has created a lot of micro-and nano plastics in an alarming rate. The question is, would the COVID-19 crisis prompt innovation for waste reduction, as it had for virtual health access, small business e-commerce, community collaboration and more? This review suggests recent environmentally friendly and sustainable plastic waste management practices. Plastic waste would be a thing of the past through the most recent molecular re-engineering technique which combined two super enzymes, PETase and MHETase which yielded a faster breakdown of PET. Also, plastic waste can be fought through the use of underwater robot called Smart Infrared Based Remotely Operated Vehicle to identify microplastics in marine environments. The 
Remotely Operated Vehicle; LMI: Lower Middle-Income; UMI: Upper MiddleIncome; HI: High-Income; LI: Low-Income way forward towards a near-zero plastic waste in the ongoing-and post-COVID-19 era demands that we let go business-as-usual and simultaneously adopt the System Change Scenario concept. If returning back to normal is not an option, perhaps the best hope we can find in our present situation is this: there is no better time for change than now. The COVID-19 pandemic is an eye opener towards a need for cooperation among individuals, expert organizations, and the government for a more sustainable environment.

Keywords: COVID-19, Surge in Plastic Waste, E-Commerce and Health Sectors, Singleuse plastics, Public and Environmental Health, Micro-and Nano plastics, Molecular Reengineering, Underwater Robots, Business-as-usual, System Change Scenario, Near-zero Plastic Waste

\section{Introduction}

The world is faced with grip of coronavirus disease 2019 (COVID-19) pandemic due to its unprecedented impact that has never been seen before and has caused untold human suffering, social upheaval, and economic damage [1]. In a way to slow down and curtail the spread of COVID-19 the lockdowns took effect and brought about a brief press on the pause button of environmental degradation which resulted to dramatic reductions in air and water pollution [2] but this was not the case with solid waste pollution as seen in the surge of plastic wastes which is a threat to the planet [3-5] and extraordinary efforts would be required to transform the global plastics economy [6]. Bank et al. [7] and Kane et al. [8] opined that plastic pollution is universal and currently being viewed as an emerging environmental and human health crisis. Three-quarters of the land and two-thirds of the ocean have significantly been altered by human activities thereby changing the planet to such an extent as to determine the birth of a new era: the "Anthropocene" [1]. Velis and Cook [9] described their visit to a bookstore in which they could not help themselves rather than to stare at a display unit featuring no fewer than ten books stating how to get rid of plastics from one's daily life. They said that "we are bombarded with information on marine litter and plastic pollution yet how much do we really know about this problem?" People know close to nothing about how and where plastic waste is generated, managed, treated, and disposed.

As a result, we are struggling to limit the amount of litter accumulating in the environment. No wonder plastics are referred to as the known-unknowns [10]. At a time where the fight against the pressing environmental destructive issue was absolutely necessary and had started making a headway in the year 2019 in relation to the reduction in the use of plastics [11] then here came the sudden ravaging novel COVID-19 pandemic that even needed a much more immediate global attention $[12,13]$ which has threatened to stall and even reverse the progress made thus far on plastic waste management [14]. The novel COVID-19 has brought about an easy ride in the use of plastics which is being utilized in various sectors [15] just shortly after the community of nations/companies had agreed/made many commitments in the reduction of plastics use [11]. Prior to the pandemic, supermarkets and manufacturers had established packaging as an urgent priority towards the end of 2019 in order to safe nature. However, sustainability was pushed down the priority list since the industry dealt with a more demanding and pressing need to feed the nation amid huge supply chain disruption while keeping employees safe [11]. But the big pertinent question remains, how is the industry weighing safety against environmental concerns? Commitment was made by Sainsbury's departing CEO of Mike Coupe, who laid plans to halve the supermarket's plastic packaging by 2025 .

Also, Tesco unveiled its plan to remove one billion pieces of plastics from products in UK's stores by the end of 2020. Not forgetting, Asda accelerated its own plastic reduction commitment by five years. Unilever Nestle and Pepsi Cola also made their commitments but there is no doubt that the landscape has changed since those commitments were made prior to the issue of the coronavirus pandemic [11]. A published report by Toronto Star daily on $22^{\text {nd }}$ June 2020 stated that, "the COVID-19 crisis has led to 'a global resurgence in single-use plastic,' particularly around plastic bags and nonrecyclable personal protective equipment (PPE), and the result could be both ecologically and economically harmful" [16]. Precisely $22^{\text {nd }}$ September 2020, Honduras experienced a Massive trash 'tsunami' filled with plastic debris which plagued and invaded Honduras beaches. Authorities believed the Massive trash came from a river in neighboring Guatemala. Video clip showed trash bobbing in the ocean - loads of it piled along the shoreline. The eyesore has taken an economic toll on the area's tourist-dependent beaches [17]. In 2019, the group Break Free from Plastics organized over 70,000 volunteers in 51 countries to collect and identify plastic waste. They collected over 59,000 plastic bags, 53,000 sachets and 29,000 plastic bottles as reported by the Guardian. Nearly half of the items collected were linked to Coca-Cola, Nestle and Pepsi Cola [18,19].

According to an ING survey, Europeans dispose an average of three pieces of plastics waste every day. Plastic waste has become a very tangible environmental problem that people come face-toface with every day. In April 2020, Defra confirmed the UK's ban on plastic straws, stirrers and cotton buds would be delayed for another six months to avoid additional burdens for firms at this challenging time [11]. More than one-fourth of the resins globally used in the production of single-use plastics are manufactured in 
North East Asia. This is followed by North America, Middle East, and Europe [20]. The most common thermoplastics are polyethylene terephthalate (PET), polypropylene (PP), low density polyethylene (LDPE), high density polyethylene (HDPE), polystyrene (PS), expanded polystyrene (EPS), polyvinyl chloride (PVC), polylactic acid (PLA), polyhydroxy alkenoates (PHA). These thermoplastics can be melted when heated and hardened when cooled, hence they can be reformed and reshaped [20]. The most common thermosets are polyurethane, phenolic resins, epoxy resins, silicone, vinyl esters, acrylic resins, urea formaldehyde resins (UF). These thermosets after heated and formed cannot be melted and reformed [20].

According to UNEP [20], the main polymers used in production of single-use plastics include:

i. LDPE: bags, trays, containers, food packaging film.

ii. PS: cutlery, plates, and cups.

iii. HDPE: milk bottles, freezer bags, shampoo bottles, Ice cream containers.

iv. PET: water bottles, dispensing containers.

v. PP: microwave dishes, ice cream tubs, potato chips bag, bottle caps.

vi. EPS: hot drinks cup, insulated food packaging, protective packaging for fragile items.

The biodegradation process of plastics in the ocean takes over 500 years which implies that masks and as well as gloves which are made from cheap and durable plastics such as polyvinyl chloride (PVC) or nitrile butadiene rubber (NBR) are a non-biodegradable material with a very long shelf life will be in nature for a long time [15]. In a report by Brownlee [16], the \$13-million landfill in Muskoka district in Central Ontario of Canada that was opened up in 2016 is currently the last active landfill, and it is estimated to reach its 950,000 -tonne capacity by 2041 , unless waste diversion improves most especially with the COVID-19 situation.

As a matter of fact, there is a huge struggle with nonexistent or broken waste-management infrastructure in many developing countries. The presence of COVID-19 crisis highlights the need for cooperative action, and now is the moment to establish such a change $[14,21]$. An impact analysis on Global Waste Management Market in the light of COVID-19 by Acumen Research and Consulting that considered its baseline data from 2019 clearly revealed that plastic management will be over $\$ 41.1$ billion by 2027 and the market is anticipated to display a compound annual growth rate (CAGR) of 3.3 percent from 2020 to 2027 [22]. In this era of COVID-19, the use of plastics is on the rise in both e-commercial and health sectors. Hence, this review investigated the challenges facing humanity in association to public-and-environmental health risks generated by resurgence of excessive plastic waste and the more sustainable option in the ongoing COVID-19 and Post-COVID-19 era.

\section{Plastics Utilization in the E-Commerce Sector in the Ongoing Covid-19 Era}

According to the World Bank Group, e-commerce in this context is defined broadly as the sales of goods and services online. Coronavirus has impacted the whole e-commerce of the world; it has changed the nature of businesses. According to research, 52\% of consumers are avoiding going to brick and mortar shops and other crowded areas. Furthermore, 36\% are avoiding brick and mortar shops until they get the coronavirus vaccines [23]. Overall sale of e-commerce increased because of the virus, people avoiding to go out, keeping social distancing and buying from home [23]. Due to response to the COVID-19 pandemic, the global plastic packaging market size is projected to grow from USD 909.2 billion in 2019 to 1012.6 billion by 2021, at a compound annual growth rate of 5.5\% [24]. The coronavirus crisis has already led to some of the sharpest declines in recent times in the demand for certain types of packaging while accelerating growth for others such as packaging for e-commerce shipments that are emerging as lifelines in this new world [25]. Feber, et al. [25] predicted in their April 2020 report that consumer packaging demand is likely to shift drastically in the food area as the pandemic shuts down restaurants and food services outlets, consumers will continue to move to grocery purchase for which packaging demand will rise. They also predicted that the COVID-19 crisis will make consumers around the world to increasingly incline to buy their products through online channels from what they used before the pandemic, which will lead to a strong acceleration of e-commerce shipments.

In some places, suppliers of print and packaging raw materials and production facilities have been declared as essential businesses as a result in order to keep goods moving. The pressure on packaging will only grow, many are turning to e-commerce for their retail needs which requires more packaging for shipping [26]. Susan Hansen, a global strategist for supply chains at Rabobank said, "The Coronavirus pandemic has created a sea change in public attitude, plastic went from villain to hero, consumers want it back for hygiene reasons because they feel it is safer" [11]. The plastic industry seized the pandemic as an opportunity to try to convince people that single-use plastic is necessary to keep us safe and that reusable are dirty and dangerous as reported by John Hocevar, Ocean Campaign director at Greenpeace [27]. Coronavirus pandemic has provoked the food packaging debate, with some using the crisis to hammer home the message that plastic is vital for protecting food from germs and extending its shelf life, while others stress the pandemic highlights the fact that disposable plastic is unsustainable [28]. Sedat Gundogdu, an expert on Seawater and Microplastic at Turkey's Cukurova University, reported that plastic producers took advantage of COVID-19 and people's hygiene concerns to encourage the consumption of more plastics. He said that "It is questionable that using plastic packaging will provide a hygienic precaution against COVID-19, encouraging people to use plastics is not based on any scientific established information and is even misleading". 
He added that, trying to profit from people's virus concerns is not only unethical but also incompatible as part of public health. Restating that the current plastic consumption is many times more than the pre-coronavirus consumption, Gundogdu warned that this will cause some serious problems such as microplastics in the longterm [29]. Gary Hemphill of the Beverage Marketing Corporation carried out a statistical analysis for his company and found out that beverages and bottle water had experienced a particular sales surge in March 2020 [30]. In Italy, consumers spending on packaged Mandarins rose to over 111\% in March 8, 2020 in comparison to a year ago. This resulted in a demand for plastics amid the Coronavirus pandemic, says Barry Turner director of Plastic and Flexible Packaging at the British Plastic Federation [28]. The COVID-19 pandemic has ignited an upsurge in take-out delivery orders and consequently single-use plastic containers waste. Particularly polystyrene, the material used to make styrofoam is experiencing a renewed demand due to the pandemic [31]. The surge in single-use plastic is a major blow to fight against plastic pollution which is projected to increase by $40 \%$ in the next decade according to a report from the World Wildlife Fund. The problem is especially apparent in the restaurant industry and its increased reliance on food delivery services [27].

The choices by individuals during lockdowns increased plastic demand. When the eight-week lockdown in Singapore was imposed, packaged take-out meals and home delivered groceries contributed an additional 1400 tonnes of plastic waste [32].

\section{Public Health Consequences on Plastics Utilized from E-Commerce}

In a letter written to the US Department of Health and Human Services by the American Plastics Industry Association, it claims that "Single-use plastic products are the most sanitary choice especially in the consumption and transportation of food purchased at a restaurant or at a grocery store". The association cited four pieces of evidence to support that reusable bags are bad for the pandemic stating that "study after study have shown that reusable bags can carry viruses and bacteria, spread them throughout a grocery store and live on surfaces for up to three days". But, Sian Sutherland, co-founder of an International Campaign Organization, A Plastic Planet disagreed, she believes that the plea by the American Plastics Industry Association for single-use plastic restrictions and plastic bag bans to be reversed is extreme. She said, "No other material manufacturer is jumping on the COVID-19 bandwagon for their own benefit in such a way. The virus is already shown to last a third of the time on cardboard than on plastic and yet that industry is not using this as an opportunity to lobby or directly profit from the crisis." She added "I don't understand the science of suddenly saying single-use plastic bags are the answer when it's the cashier that is handing the bags over to you. The overriding message should be to own your own bag, keep it to yourself always and wash your hands".
She believes that this is a time when we all are fully aware that plastic packaging is devastating to the natural world, our societal and economic and environmental systems, yet we can also witness the Environmental Protection Agency in the United States lifting restrictions on industrial polluters. This huge backward step presents a problem for our near future [28]. Similarly, Carol lends her voice on the need not to return back to the ban on single-use plastic based on the compounded policy gaps being witnessed because we are thinking short-term about the immediate need, which is understandable, but we're not thinking long-term consequences. She said, "with virgin plastic becoming so cheap, she questioned whether there would be 'a real focus on using recyclables or investing in recyclables' in a pandemic-ravaged economy" [33]. Also, Nott [11] found out that the virus lasts 24 hours and 72 hours on cardboard and plastics, respectively.

\section{Plastic Utilization in the Health Sector in the COVID-19 Era}

Barry Turner, director of Plastic and Flexible Packaging at the British Plastic Federation said, "There has been a massive uprising from certain sectors such as NHS and all sort of situations where food still has to be served within a closed environment for the sort of things like plastics that people have been calling on to be banned" [28]. Since more plastics are being used in the ongoing pandemic era, it therefore means that more will find its way into nature. In Hong Kong for example, 70 masks were found within 100 meters of a beach, with some still looking brand new. This poses the question by Way [15] on, "how much more personal protective equipment (PPE) has been used during the pandemic to cause this alarming increase of 'PPE litter'?" An NHS trust in Lincolnshire, England, recently reported a total of 72,000 PPE from four hospitals in the trust each day which spread across, 39,500 masks, 11,495 gloves, 1,501 gowns, 4,201 respirator masks as well as aprons and eye protectors were used. Therefore, considering the 226 trust in the UK, it suggests 10 million or more PPE items are in use each day and most are single-use plastics [15]. The distribution of PPEs to health and social care services in England just within a four-month period (i.e. from February to July, 2020) was about 2.3 billion items, whereas the same amount was distributed in the whole of 2019, indicating an increase in single-use PPE being distributed [15].

The significance of PPE to health workers cannot be overemphasized nor disputed. Although a lot of funds have been spent by the UK government which has accrued to well over $£ 15$ billion on PPE for the pandemic, which equates to around $£ 500$ from each UK taxpayer. Despite the effort by the UK's government, there are still nationwide shortages, often down to the nonreusability of the equipment thereby leading to ordering supplies from abroad, which in some cases has led to further plastic waste. A classic example was when 100,000 gowns bought from China were rejected after not reaching the standard required [15]. According to Way [15] a lot of plastics have been observed in the UK's COVID-19 
home-testing kits that was sent out to collect saliva samples. A kit can contain four plastic bottles with lids, eight plastic bags, one elastic band, eight peel-off labels, two lint pieces in a plastic/paper pack and paper/bubble wrap envelope (Plate 1). Also, the kit has spares of each item, with no instruction on whether spares can be returned or how to be disposed of correctly. The kit was sent out to about 14,000 people, which could lead to 84,000 "spare" plastic bags and 42,000 "spare" plastic bottles. In March 2020, the doctors and administrators at the University of Nebraska Medical Center in the United States had calculated that if they continued to use masks only once, they would run out of masks in just weeks [34]. By late June 2020, cities and states had temporarily suspended almost 50 single-use item reduction policies across the United States.

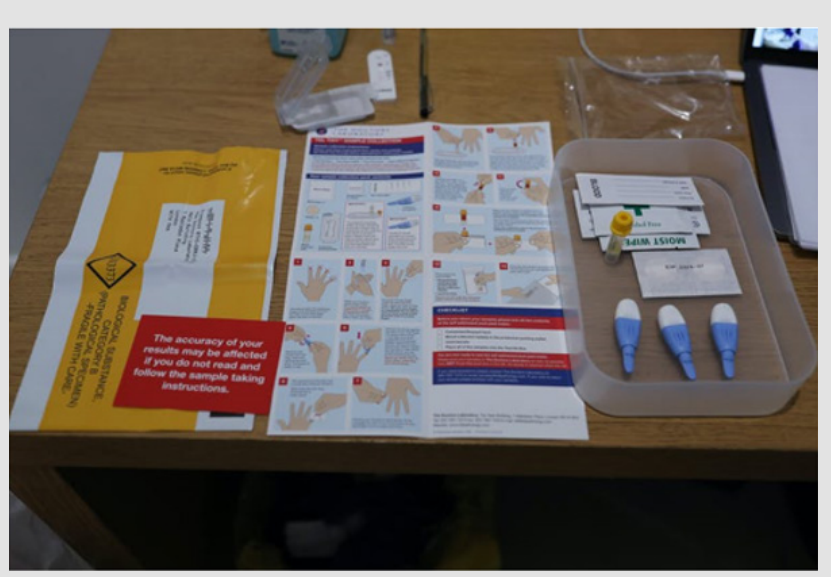

Plate 1: A home COVID-19 antibodies test kit containing plastic spare for each item that cannot be used by others even if it was not used (Source: [15]).

The pandemic also spurred demand for single-use personal protective equipment such as face masks and plastic gloves suggesting a significant rise in production. These items soon began appearing in municipal solid waste streams and discard on streets [35]. In China, the Ministry of Ecology and Environment estimated that hospitals in Wuhan produced more than 240 tons of waste daily at the height of the outbreak, compared with 40 tons during normal times. Based on these data, the consulting firm Frost \& Sullivan predicts that the United States could generate an entire year's worth of medical waste in just two months because of COVID-19. In China, daily production of face masks soared to 116 million in February, 12 times higher than the previous month [14].

\section{Disposal of Plastic Waste in the COVID-19 Era}

The fact remains that the coronavirus pandemic is also having an impact on recycling efforts. Plastic redemption centers are witnessing low volumes over the period of lockdown with an increase in household wastes [14]. Globally, environmental leakage of plastics is dominated by mismanaged waste treatment, primarily in the form of open dumpsites [36]. According to the Hong Kong based NGO, Ocean Asia, approximately 300 million tons of plastic is produced worldwide every year with more than 8 million entering oceans annually and ultimately threatening the ecosystems of marine wildlife. The COVID-19 pandemic threatens to further exacerbate the scourge of plastic pollution [37]. The socialdistancing rules and stay-at-home orders have compounded the disposal and management of waste. In the US, curbside recycling pickup has been suspended in many places, including parts of Miami-Dade and Los Angeles counties [14] which is resulting to pile ups in the environment. In the United Kingdom, so-called fly-tipping - illegal waste disposal - has risen by $300 \%$ during the pandemic. In some countries, companies that are advancing innovative methods of recycling and reusing waste plastics are reporting reduced amounts of plastic coming through waste streams, suggesting that a growing volume of plastic is ending up in landfills or leaking into the environment [14].

\section{Plastic Waste Load Generated and Disposed from E-commerce Sector in the COVID-19 Era}

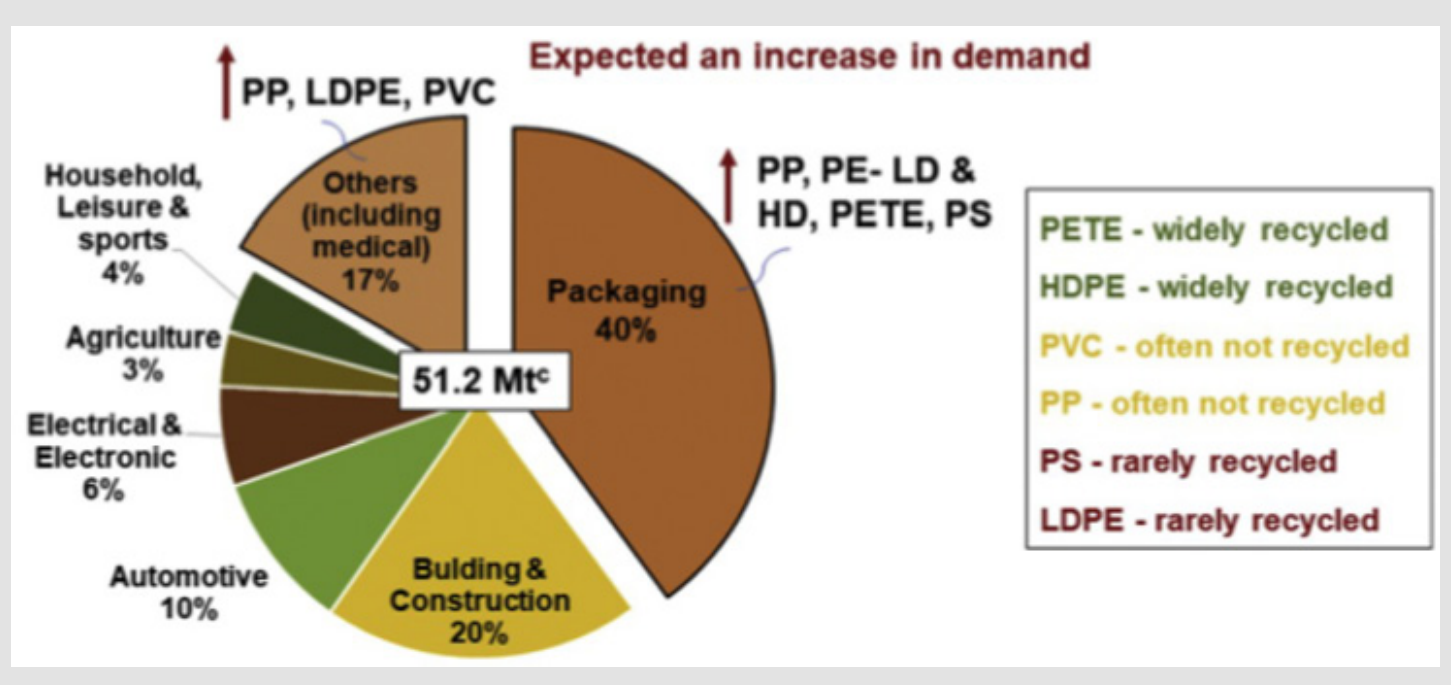

Figure 1: Plastic demand by segment and the expected increasing trend in packaging materials (Source: [39]). 
The report by Heller, et al. [36] explained the scale of plastic flow across stages in the US in 2017, 27\% of raw plastic polymers used in plastic production are used in packaging. Stating that in the plastic production, $41 \%$ is used for containers and packaging, $21 \%$ is used for non-durable plastic goods and 38\% used for durable plastic goods. The report then explained that from the waste generated, only $8 \%$ is recycled, $14 \%$ is combusted, $76 \%$ is landfilled and the remaining $2 \%$ goes as leakages. In a study on the concept of plastic waste footprints (PWF), e-commerce packaged goods which include food delivery or take-out as well as grocery delivery which were already in high demand [38] was expected to be the most demanded item comprised of PP, LDPE, HDPE, PETE and PS in the COVID-19 era by $40 \%$ as shown in (Figure 1) [39] which at the long run will directly translates into being the most dominantly disposed waste in the environment. According to the Thailand Environment Institute, plastic waste has increased from 1,500 tonnes to 6,300 tonnes per day, owing to soaring home deliveries of food [14]. A report by WWF calculated the total plastic waste generation in the Uk in 2014 to be around 4.9 million tonnes and estimated to increase to 6.3 million tonnes by 2030 with plastic packaging making up to two-thirds of the plastic waste in 2014 (3.3 million tonnes) [40].
More than one-third of plastics waste come from single-use products and packaging as reported by Oceana a Canadian ocean conservation organization [41]. Boyle [33] pointed out that the e-commerce embraces by many on the to-go market in order to stay afloat have yielded a mountain of plastic utensils, containers, cups, and boxes. Similarly, Brownlee [16] stated that the Muskoka district in Canada had over 7\% increase in waste between $1^{\text {st }}$ March and $31^{\text {st }}$ May 2020 in comparison to the same period last year, while commercial garbage had decreased $11 \%$. It is insufficient to predominantly use carbon emission to measure environmental impact. There are underlying problems - unlike clear blue skies, a growing mountain of plastic waste which isn't quite visible to us. The overwhelming increase in single-use plastic consumption compounding waste problem. E-commerce activity has spiked, as consumers order everything they can't buy outside thereby resulting to a fast piled up waste of packaged deliverable products as shown in (Figure 2). In China, packaging material accounted for 9.4 million tonnes of waste in 2018 and most likely to hit 41.3 million tonnes by 2025 - without accounting for the surge in packaging demand during the pandemic [42]. With the pandemic in view the amount of packaged waste may double (82.6 million tonnes) by 2025 .

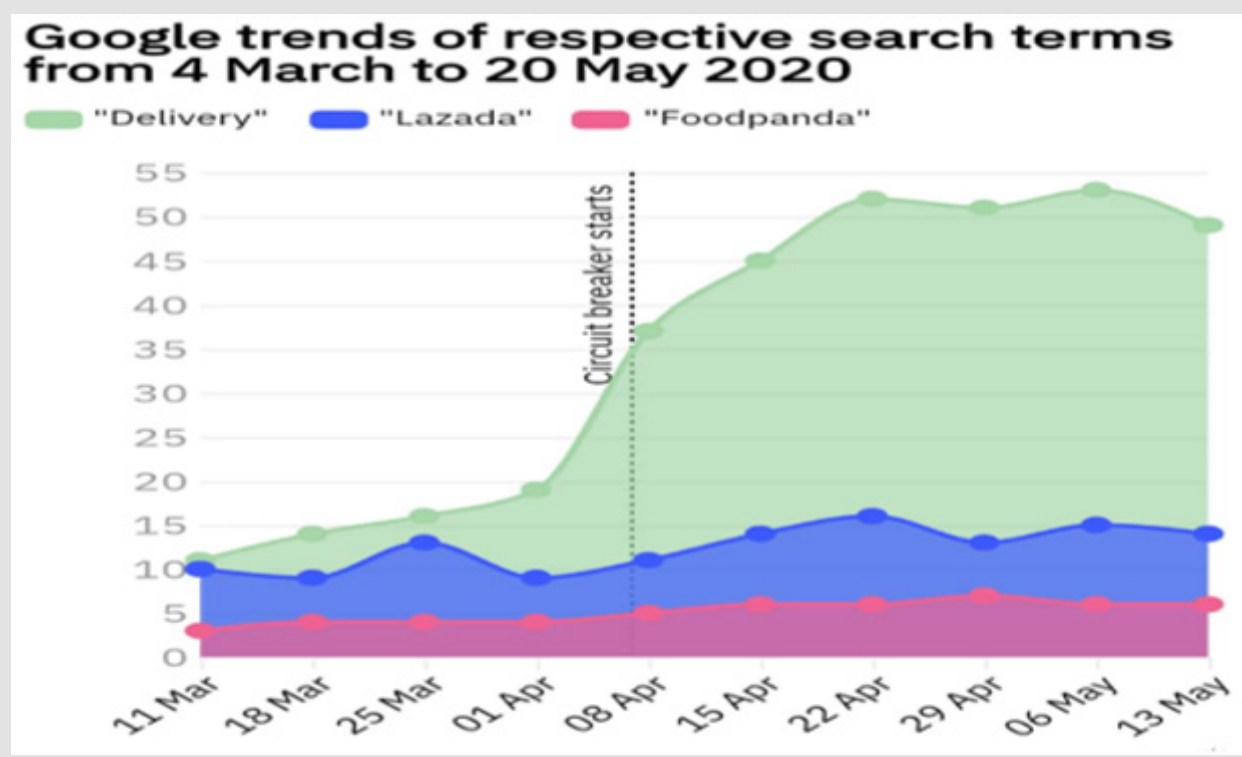

Figure 2: The trend of three terms in relation to their demand between March and May, 2020.

Methodology Note: Numbers represent search interest relative to the highest point on the chart for the given region and time. A value of 100 is the peak popularity for the term. A value of 50 means that the term is half as popular (Source: [42]).

Cheng [42] found that Bangkok city in Thailand currently produces $27 \%$ more plastic waste compared to before the pandemic — an additional 1,700 tonnes a day. Plastic waste in Southeast Asia looks like a beast that they are yet to conquer, and the amount of plastic waste being generated due to the pandemic is very high. In the US Environmental Protection Agency method, plastic containers and packaging are assumed to be discarded in the same year that the products they contain are purchased. Non-durable plastics are described as those that generally last less than three years and include plastic plates, and cups, trash bags, disposable diapers, clothing and footwear [36].

\section{Plastic Waste Load Generated and Disposed from Health Sector in the COVID-19 Era}

Before the COVID-19 pandemic, single-use plastic bags and foamed plastics (Styrofoam for food containers) are mostly 
disposed but currently, surgical face masks, plastic hand gloves have joined the list [20]. The Ocean Conservancy pointed out that the global population is set to consume 129 billion face masks and 65 billion single-use gloves per month due to the ongoing COVID-19 regulations. University College London UCL, UK, estimated that 124,000 tonnes of plastic waste will be generated in the UK if each person uses a single use mask per day for a year [31]. Medical PPE includes respirators, masks, face shields, goggles, gowns, coveralls, gloves and more, all of which are made from plastic materials and are little used before disposal. Respirators and surgical masks are made from polypropylene and can take up to 500 years to degrade in the ocean, similarly gloves are made from polyvinyl chloride PVC or nitrile butadiene rubber NBR making them non-biodegradable with a very long shelf life. About 70 masks were found within 100meter of a beach in Hong Kong with some still looking brand new [15]. Of the millions of facemasks produced in China, hundreds of tonnes of discarded masks were being collected daily from public bins alone during the outbreak's peak; most likely much more were being discarded in household waste systems [14].

French nonprofit operation Mer Propre said they have already found gloves and face masks in the Mediterranean Sea. The Group 4ocean, which cleans up beaches in the United States and across the world said they have found hundreds of masks and gloves in their limited beach clean ups since the lockdown has been lifted [43]. Duer [14] clearly stated that, "there have been widely circulated images of plastic sacks of medical waste piling up outside hospitals, and used personal protective equipment floating in coastal waters and washing up on the world's beaches, illustrate yet again the dark side of single-use plastics. Thus, if we are not careful, shortterm thinking during the pandemic could lead to an even larger environmental and public health calamity in the future." The report from ABC News Network by Schlosberg, et al. [43] showed that communities across the United States have seen examples of increased litter during the coronavirus pandemic. Especially surgical face masks and gloves discarded on the ground and environmentalists are concerned with the increased use of singleuse plastics like masks, gloves, bags, and disposable silverwares which will lead to more plastic waste making its way into the ocean.

\section{Micro-and-Nanoplastics Impacts on Public and Environmental Health}

Plastics have a lifespan of approximately 450 years, and never fully degrade but shrinks into smaller pieces of plastics called microplastics (MPs) [37]. Along with the increasing number of plastic wastes, Gundogdu pointed out another problem of microplastics in hygiene products such as detergents and soaps containing chemicals that reach the wastewater sources and then into freshwater sources and finally the sea [29]. The concern on MPs is becoming more alarming [4] due to its non-negligible risks on human health [44]. Recently, Free et al. [45], Desforges et al. [46] and Gil-Delgado et al. [47] reported the abundance of MPs particles in shrimps, fishes, and ducks across the ocean around the world in which plastic to fish ratio by 2050 will be $>1: 1$ (Plate 2). This occurs as a result of daily interaction with microplastic particles in food webs which get into organisms through different ways such as oral, dermal, and inhalational exposure [48]. Microplastics toxicity is also linked with the potential toxicity of its next form: nano plastics. A potential concern raised by microplastics is that if they further break down to the Nanoplastics level, the toxicity of microplastics can be significantly amplified. Nanoplastics can enter the gut or the respiratory tract and aggregate in the systemic circulations and tissues [44]. Microplastics are plastic fragments less than $5 \mathrm{~mm}$ or about 0.2 inches in diameter while nano plastics are even smaller, with diameters less than $0.001 \mathrm{~mm}$.

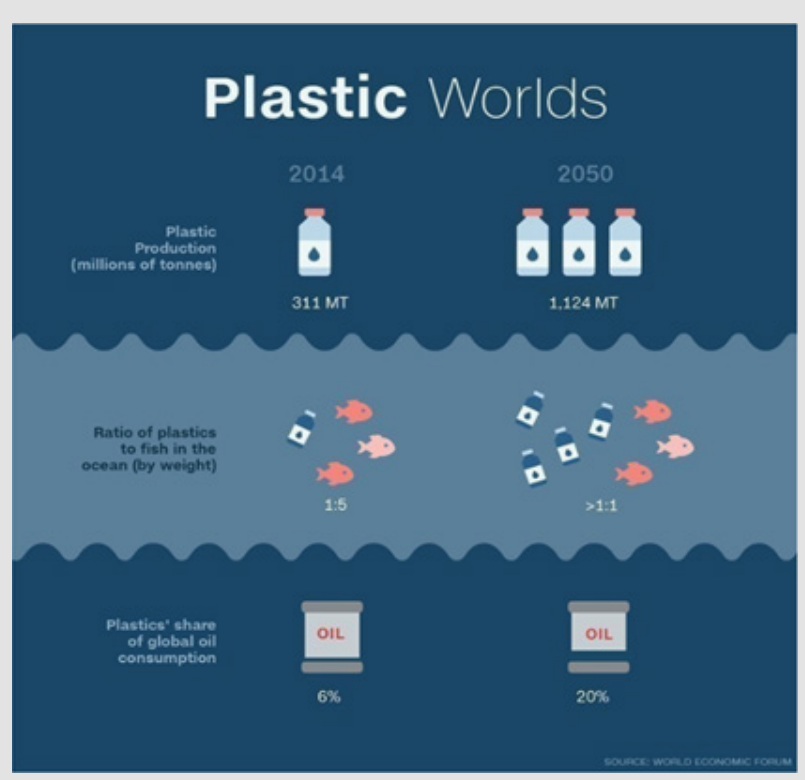

Plate 2: Plastic production, ratio of plastics to fish in the ocean, and plastics' share of global consumption between 2014 and 2050 (Source: [49]).

The American Chemical Society [50] is the first to evidently establish the occurrence of micro-and-nano plastic in human organs from individuals with a known history of environmental exposure sources and routes. They pointed out that these plastics can enter and accumulate in human tissues thereby resulting to a potential health risk. There is a potential risk of tissue inflammation once the aggregates of nano plastics in tissues surpass a threshold concentration [51]. Scientists from UK have discovered the highest level of microplastics ever recorded on the seafloor, with up to 1.9 million pieces of plastics covering just one square meter at the bottom of the Tyvrhenian Sea, part of the Mediterranean Sea off the western coast of Italy [52]. Ocean microplastics have created waste areas such as the Great Pacific Garbage Patch, a massive gyre of more than 87,000 tonnes of trash spanning waters from the west coast of North America to Japan. According to research, these microplastics attract vital ecosystems to consume them thereby disrupting the development and reproductive health of marine animals. This is evident as scientists have found microplastics in 114 freshwater and marine species [52]. 
While it is still unclear, some studies suggest that plastic bags and Styrofoam containers can take long time to decompose, contaminating the soil, water and posing significant ingestion, choking and entanglement hazard to wildlife on land and in the ocean. Styrofoam used for food containers contain styrene and benzene which are carcinogenic and have adverse effects on respiratory, nervous and reproductive systems [20]. High concentration of plastic materials has been found blocking the breathing passages and stomach of hundreds of different species. Plastics in the ocean resemble Jelly fish and are often ingested by Turtles and Dolphins. This eventually enters into the food chain of humans as well. When plastics breakdown into microplastic particles, it becomes even more difficult to detect and remove from open oceans [20,53]. Jambeck, et al. [53] stated that by 2050, an estimated $99 \%$ of seabirds would have ingested plastic. Marine litter harms over 600 marine species and $5 \%$ of the affected species are endangered. Evidence have shown that microplastic surfaces in aquatic environments host microorganisms that are resistant to antibiotics $[54,55]$ which suggests that plastic pollution could have ramifications on disease transmission and treatment in addition to environmental consequences and human exposure to contaminated air, water, and food [56].

The Management of Plastic Production and Utilization in Relation to Ongoing COVID-19 Pandemic

Recently, a consumer product industry by name GreenJoys whose aim is to change community lifestyle towards contributing to the reduction of plastic waste introduced the best alternative to plastic straw, replacing it with grass straw. The Greenjoy grass straw is made entirely of natural herbaceous plants (Lepironia articulate) and can be used once for restaurants, hotels and around three times for individuals [57]. A 16-ounce bamboo container for poutine and chicken bowls was manufactured and introduced since November 2019 which has been positively acknowledged by individuals who utilized it at Ontario and Quebec restaurants in Canada said that it is more environmentally friendly [41]. A research team in South Korea developed a nano-filter that could extend the life of face masks, even after being washed more than 20 times due to the constraints on PPE during the pandemic. Similarly, Israeli researchers invented a reusable face mask that can kill the coronavirus, while a team at the University of British Columbia's Bioproducts Institute designed what could be the world's first fully compostable and biodegradable medical mask [41]. Boyle [33] opined that based on the Practice Green Health report, medical waste can be reduced through the use of reusable isolation gowns which was the case of Ronald Reagan UCLA Medical Center in 2012 who saved over \$1.1m and diverted 297 tonnes of waste after switching to reusable isolation gowns.

Coronavirus pandemic hasn't destroyed sustainability efforts altogether. Despite the upheaval, many are still pressing ahead with environmental pledges. Sander Defruyt, a new plastic economy lead at the Ellen MacArthur Foundation explains that, "While we might need to slightly tweak how we get there, there is still a clear commitment". Van Dun said, "Sustainable packaging commitments are made for the long term and are not easily abandoned" [11]. Nestle's UK \& I group packaging manager, Alison Bramfitt describes the launch of its recycled paper-wrapped smarties share pack in June 2020 as an important demonstration of its intent, despite the pandemic. Coca-Cola European partners is similarly keen to avoid going backwards during the COVID-19 pandemic. Interestingly, Pasta brand, Barilla launched a $100 \%$ recyclable packaging in the midst of the pandemic despite the increased pressure on the supply chain as stated by Alberto Costella, its marketing manager [11]. Subaru, an automaker company in America has expanded its recycling partnership with Terracycle a recycling company to include personal protective equipment PPE disposable masks and gloves across more than 20 offices nationwide. Terracycle has introduced its Zero Waste Boxes to provide a convenient recycling solution for all types of single use PPE which are not recyclable through conventional recycling [31]. Disposable masks are typically made from polypropylene plastics and can be turned into items ranging from reusable shipping pallets to plastic lumber applications [31].

Out of 54 countries in Africa, 34 have either passed a law banning plastics and implemented it or have passed a law with the intention of implementation. From the 34, 16 countries have totally banned plastic bags or have done so practically without yet enforcing regulations on the bans. This great journey began with Eritrea, an East African country in 2005, with Senegal announcing its ban on single-use plastic water sachets and coffee cups in February 2020 that was implemented in April 2020. Greenpeace Africa have taken a step to engage politicians on the issue of plastic pollution as seen in a petition delivered to representatives of each major political parties in South Africa for the inclusion of a ban on single-use plastics in their election manifestos during the 2019 national elections [58].

Way [15] revealed that there are some alternative technologies which have been implemented, tested or are currently available to tackle the issue of single-use PPE, they include;

i. The critical care decontamination system. This is a container made by a company in Ohio which can decontaminate up to 80,000 items of PPE at a single time.

ii. Scientists at the University of Nebraska are researching whether ultraviolet light can decontaminate masks and respirators.

iii. Biodegradable gloves are available which can decompose in landfill in two years.

iv. The Reelshield flip, a face visor made from paper board and wood pulp cellulose that is decomposable.

In the United States, eight out of ten states with plastic container 
redemption systems have enacted temporary measures limiting deposits returns in some way leading to significant decline in the volumes of high-quality recyclables moving to material processors [30]. Susan Collins, President of the Container Recycling Institute reported, "We are learning how critical recycling is to the supply chain and how vulnerable it is to this kind of disruption". In a report compiled by her organization in Oregon, where the Oregon Beverage Recycling Cooperative (OBRC), runs the state's container redemption systems, returns are down but not vanished. Retailers have largely suspended acceptance of containers for redemption in line with the state's emergency regulations [30]. In the first week of April 2020, OBRC's returns were at about 45\% when compared with the total redemption of the same time last year. In Michigan, Tom Emmerich, chief operating officer at Schupan and Sons, the largest processor of deposit containers in the state described the situation as "There is no supply" [30]. In normal times, Carbon Lite's Riverside, California's processing facility uses exclusively PET recovered through California's container deposit system. But in recent weeks, with the restrictions on public gathering and a move to suspend requirements that retailers redeem containers have reduced availability of deposit bales markedly [30].

Current low recycling rates can be traced to market issues including inexpensive virgin feedstock or use and handling of products (contamination with dust, soil, organics, incomplete separation of recycling streams] [36,59]. The market's drive to innovate has led to tremendous diversity in the materials (polymers, additives colors) and formats (bottles, tubs, bags) present in today's plastic packaging, which has limited the technical and economical ability to recycle these materials [36]. The need for a policy instruments [36] as shown in Table 1 will go a long way in reducing plastic wastes. Laws should be enacted at both the local and national level in order to control waste in the environment. For instance, France hopes to increase littering fines to €135 (\$151) so as to combat facemask and glove pollution. Also, enforcement of local littering by-laws by other authorities as seen in Massachusetts is quite timely [33]. The Muskoka province in Canada, for example, still planned to ban food and organic waste from landfills in future for environmental, social, and economic reasons [16]. The grocery industry should soon allow use of reusable shopping bags again, and reinstate reusable container programs, while consumers should reconsider their own habits amid the crisis, too [16]. The emerging solutions for microplastic pollution cut across the following four techniques: solvent extraction, hydrothermal processes, mechanical recycling, and pyrolysis [44].

Table 1: Policy instruments that can be utilized to reduce plastic packaging pollution and increase plastic packaging recycling rate.

\begin{tabular}{|c|c|c|}
\hline Policy Goals & Command and Control Policies & Market Based Policies \\
\hline Increasing plastic recycling rates & $\begin{array}{c}\text { Products take back mandates. } \\
\text { Landfills/disposal bans } \\
\text { Deposit refund system } \\
\text { Pay as you throw }\end{array}$ & Product taxes \\
\hline Reducing plastic consumption & Product/material bans & $\begin{array}{c}\text { Virgin resin taxes } \\
\text { Tradable permits }\end{array}$ \\
\hline Developing plastic recycling markets & Recycled content standards \\
\hline
\end{tabular}

Future Forecast and Concepts on Reduction of Plastic Wastes in the Ongoing COVID-19 and Post-

\section{COVID-19 Era}

One of the most recent approach in reducing plastic waste is through molecular genetic engineering of enzymes. The Proceedings of the National Academy of Sciences announced on 28th September 2020 that a group of trans-Atlantic scientist who re-engineered the plastic-eating PETase have now created an enzyme "cocktail" which can digest plastic up to six times faster. PETase was combined with an enzyme, MHETase found in rubbish dwelling bacterium that lives on plastic bottles. The combination of the two enzymes (superenzymes) revealed a very fast breakdown of PET plastic [60]. Fleming [49] reported a brainchild idea of Anna Du a 12-yearold girl, a student from Massachusetts who developed in 2019 an underwater robot called 'Smart Infrared Based Remotely Operated Vehicle (ROV) that Identifies Microplastics in Marine Environments.' She was inspired by a visit to the beach, where she was struck by the volume of plastic littering the sand, Du has developed an underwater vehicle fitted with an infrared camera that can detect plastic resting on the seabed. Its camera takes photos of the surface of the seabed and compares those images with a reference library she developed based on an online database. The infrared technique tells plastics apart from other types of materials. The underwater robot could be deployed someday in the war against marine plastic pollution.

There are two concepts that should be clearly distinguished and well understood in order to tackle plastic pollution as described by Stuchtey and Dillon [5] below:

i. Business-as-usual (BAU): this assumes that no intervention is made in relation to current plastic-related policy, economics, infrastructure, or materials, and that cultural norms and consumer behaviors do not change.

ii. System Change Scenario (SCS): this assumes that eight system interventions are applied concurrently, and ambitiously, for both microplastics and microplastics. This scenario benefits from the synergies between upstream and downstream interventions and is the only one that includes both

From the Plastic-to-Ocean $\left(\mathrm{P}_{2} \mathrm{O}\right)$ model by Velis and Cook [9] which combined years of accumulated knowledge on global flows of 
plastic revealed that two billion people currently do not have their waste collected and should be attended to so as to reduce waste disposal by the year 2040. All solutions required to significantly reduce plastic leakage into the ocean need to be implemented concurrently, ambitiously, and at no other time other than now as shown in (Figure 3). As collection coverage increases there should be reduction in the demand for single-use and unrecyclable plastic and the need to improve the business case for mechanical recycling [9]. Velis and Cook [9] posited that, even the best-case scenario which the world considered a concerted and immediate action from their model still witnessed an approximate 710 million tonnes of plastic waste that will be released into the environment by 2040 . Though it may sound a lot, but it would mean an $80 \%$ reduction in the levels of plastic pollution compared to what will happen with no action over the next two decades. Similarly, an analysis by Lau, et al. [61] indicated that urgent and coordinated action which combines pre-and-post-consumption solutions could reverse the increasing trend of environmental plastic pollution by $78 \%$ in the year 2040 through the use of current knowledge and technologies and at a lower net cost for waste management systems compared with that of business-as-usual.

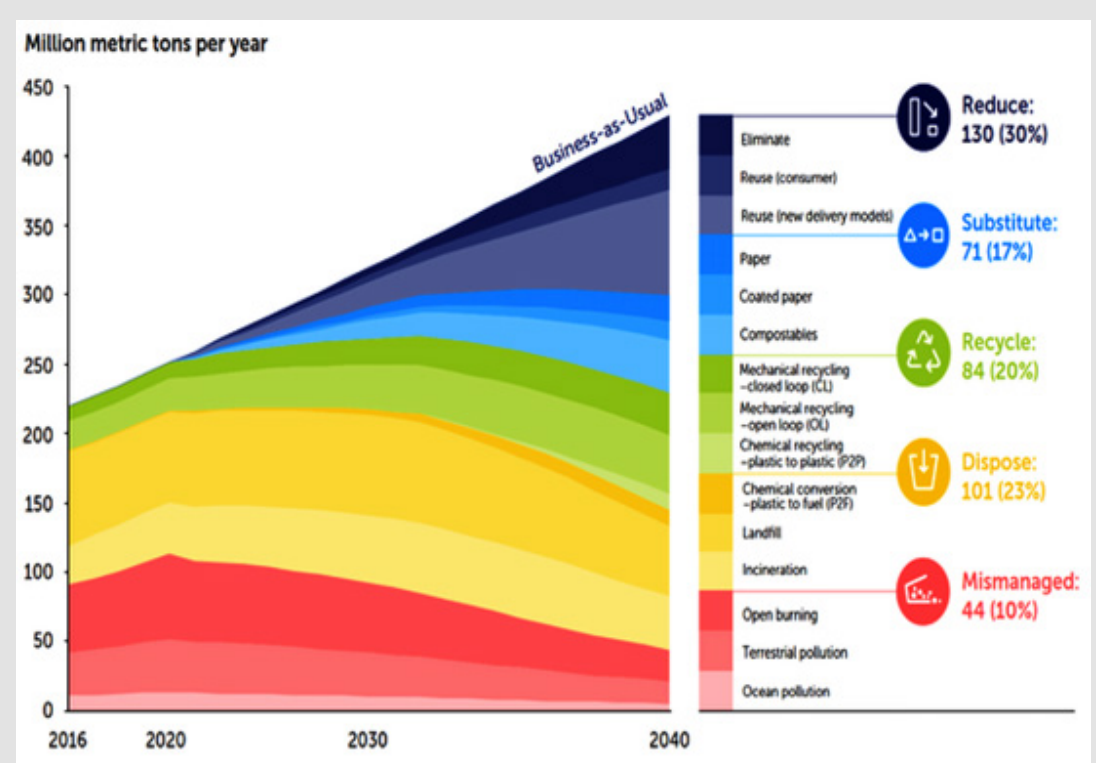

This 'wedges' figure shows the share of treatment options for the plastic thas enters the system over time under the System Change Scenario. Any plastic that enters the system has a single fore, oc a single wedge. "The numbers include macrodustic and microplassic.

Figure 3: A Concurrent, Ambitious and Timely Integrated Implementation is required to Reduce Plastic Wastes between 2016 and 2040 (Source: [9]).

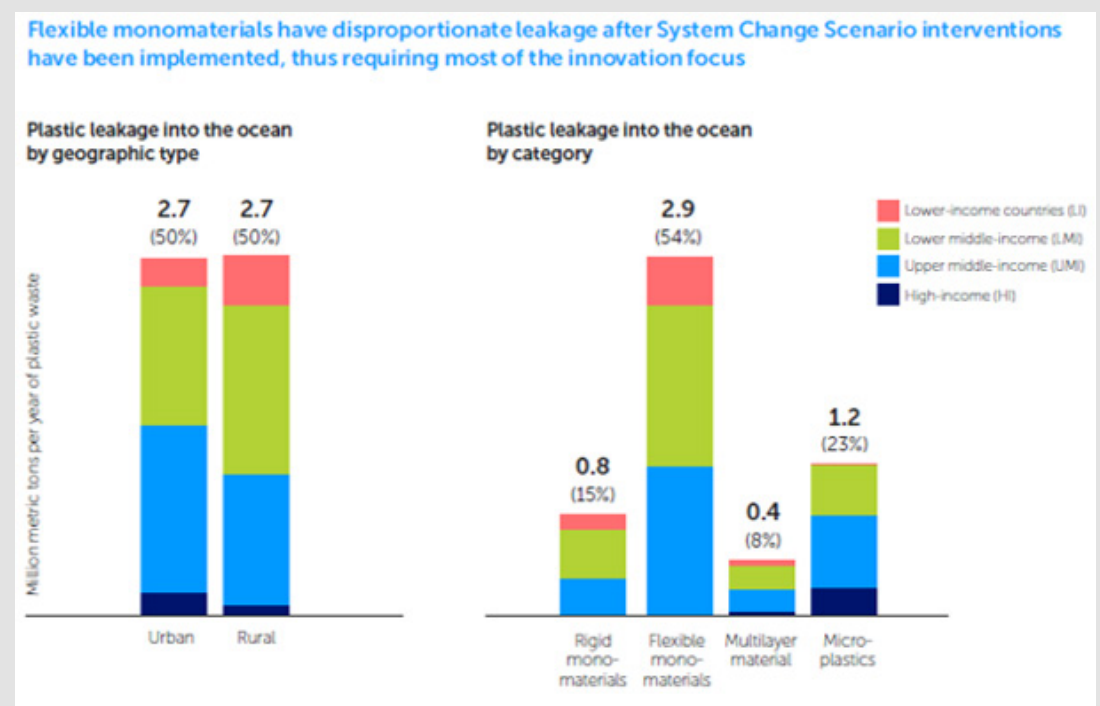

Figure 4: Remaining 2040 leakage by geographic archetype and plastic category under the System Change Scenario (Source: [5]). 


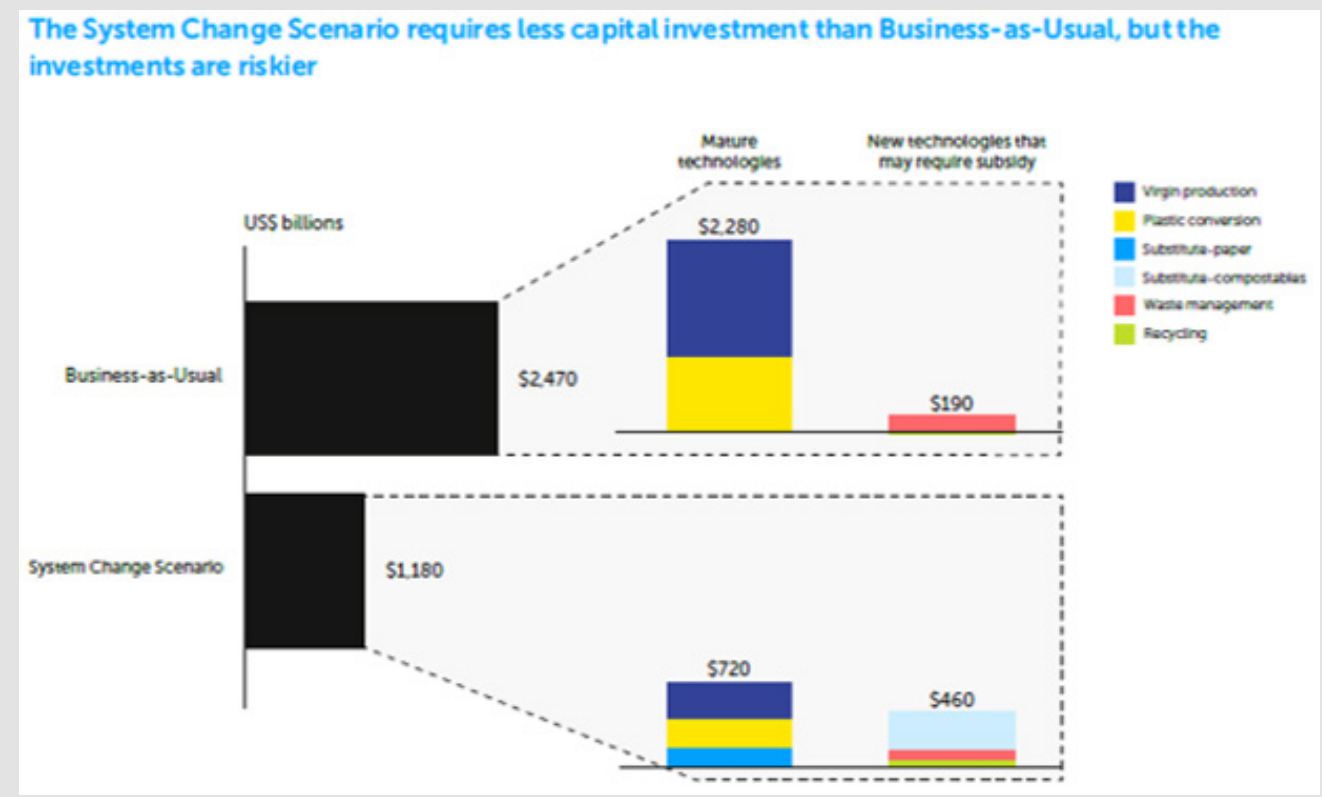

Figure 5: Present value of global capital investments required between 2021 and 2040 in different scenarios. Values in this figure represent the present value of all capital investments needed per scenario between 2021 and 2040 (Source: [5]).

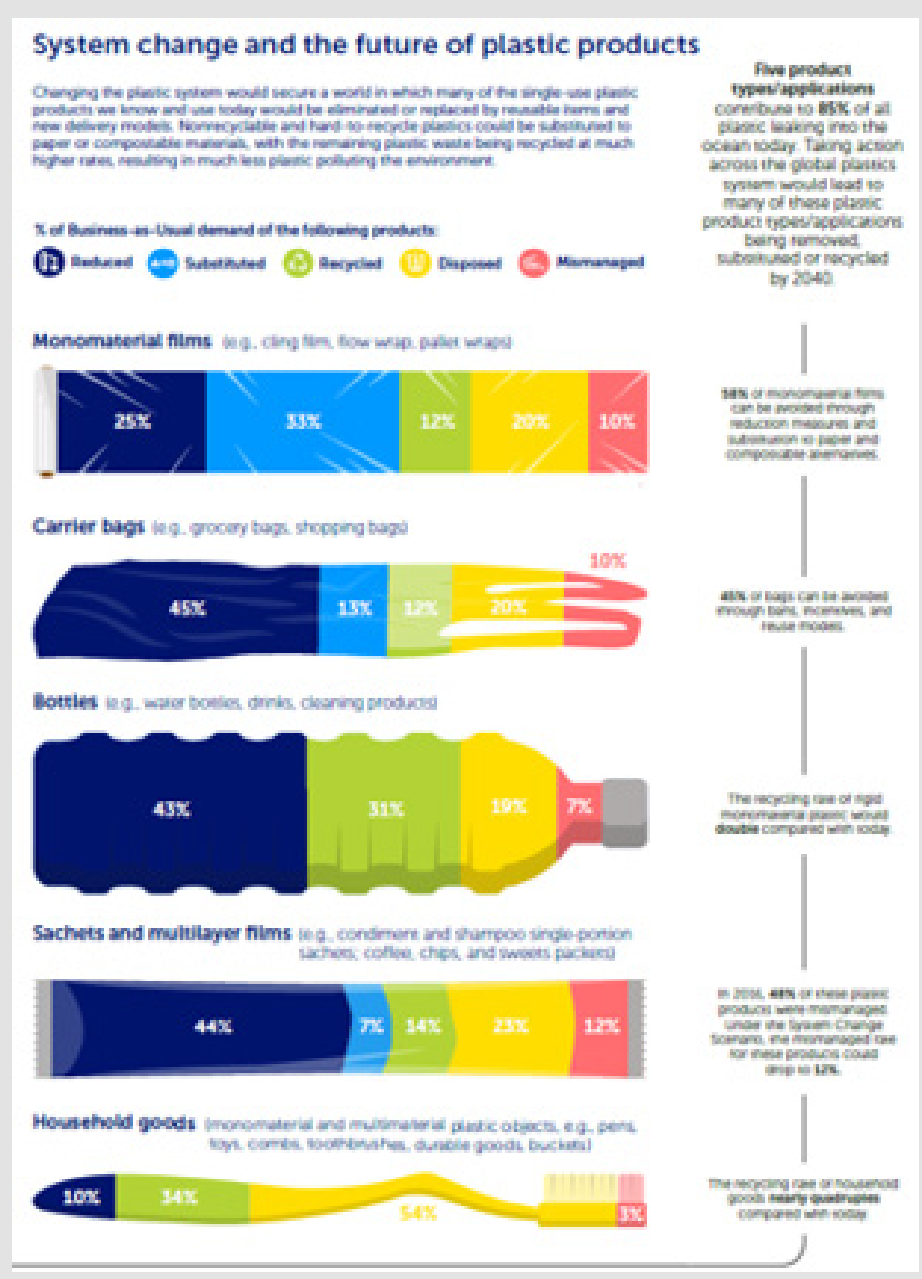

Figure 6: System Change and the future of plastic product (Source: [5]). 
A geographic archetype (rural and urban areas) and plastic category (rigid mono- materials, flexible mono- materials, multilayer material, and micro- plastics) in relation to income levels (Lower-income countries [LI], Lower middle-income [LMI], Upper middle-income [UMI], and High-income [HI]) must be taken into consideration under the System Change Scenario in order to effectively tackle leakage into ocean as shown in (Figure 4) so as to achieve near-zero plastic pollution by 2040 [5]. Solution to near-zero plastic pollution is achievable because the system change scenario is economically viable because it requires less capital investment than business-as-usual, although the investments are riskier (Figure 5). In System Change Scenario, a pragmatic substantial shift of investment away from the production and conversion of virgin plastic must take place simultaneously/ concurrently by channeling resources into new delivery models, substitute materials, recycling and collection infrastructure, which are often less mature/financially viable technologies [5]. Plastic System Change on the five product types/applications that contributes to $85 \%$ of all plastic leaking into the ocean today would secure a world in which many of the single-use plastic products we know and use today be eliminated or replaced by reusable items and new delivery models by 2040 (Figure 6).

Also, nonrecyclable and hard-to-recycle plastics could be substituted to paper or compostable materials, with the remaining plastic waste being recycled at much higher rates, resulting in much less plastic polluting the environment [5]. (Figure 6) shows that under business-as-usual demand being influenced by plastic System Change then monomaterial would be of films can be avoided through reduction measures and substitution to paper and compostable alternatives by $58 \%$. Also, $45 \%$ of carrier bags can be avoided through bans, incentives, and reuse models. The recycling rate of rigid mono material plastic would double compare with today. Sachets and multilayer films (e.g., condiment and shampoo single-portion sachets; coffee, chips, and sweets packets) plastic products in 2016 were mismanaged by $48 \%$. But under the System Change Scenario, the mismanaged rate for these products could drop to $12 \%$. The recycling rate of household goods (monomaterial and multilateral plastic objects, e.g., pens, toys, combs, toothbrushes, durable goods, buckets) nearly quadruples compared with today [5].

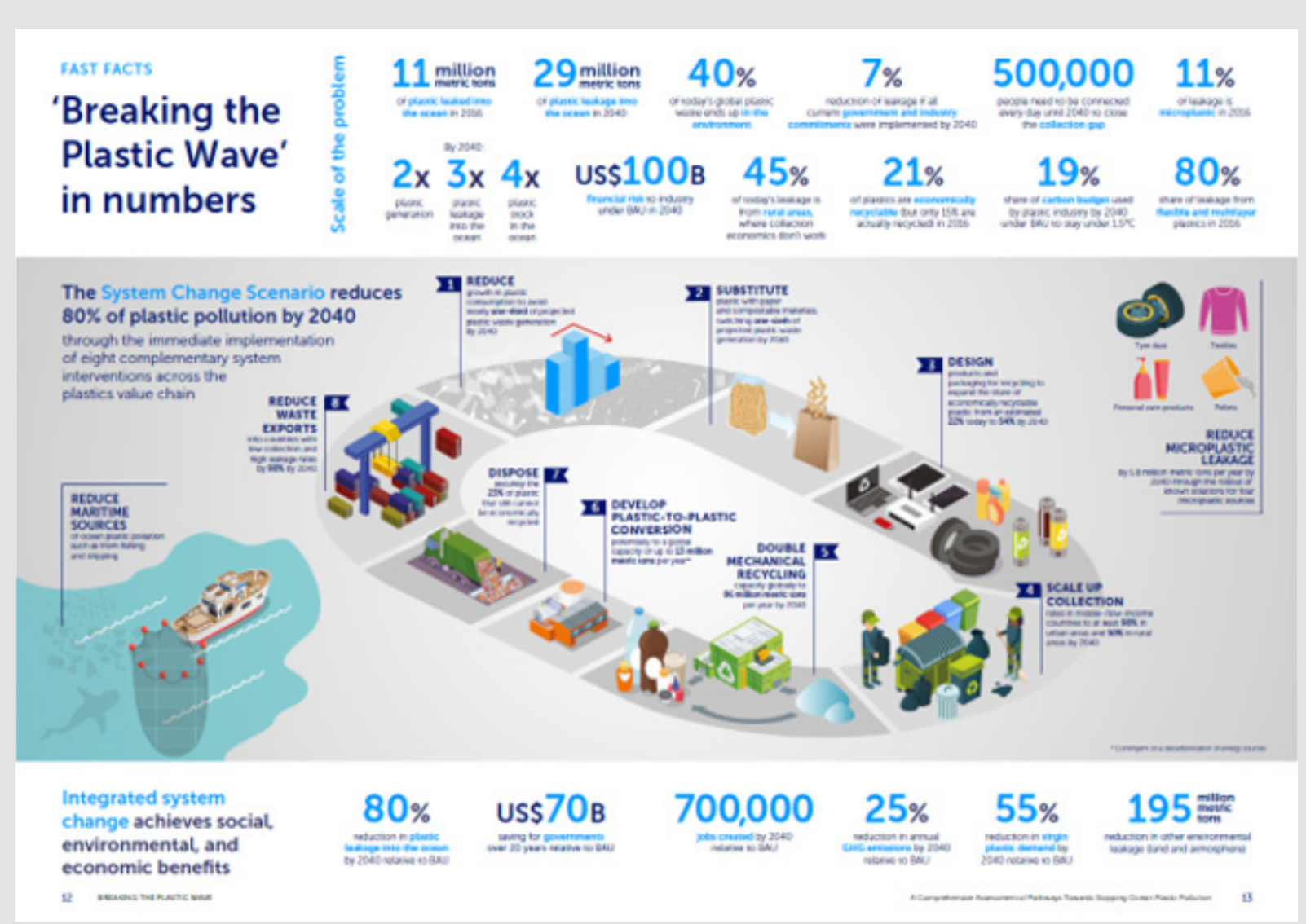

Figure 7: Breaking the plastic wave through implementation of eight complementary/integrated system interventions across the plastics value chain (Source: [5]).

By 2040 , plastic pollution can be reduced successfully by $80 \%$ through the immediate implementation of eight complementary/ integrated system interventions across the plastics value chain which include reduction in utilization of plastics, substitute plastics with compostable materials, design recyclable plastics, scaling up collection rates in middle-/low-income countries to at least $90 \%$ in urban areas and $50 \%$ in rural areas by 2040 , double mechanical recycling capacity globally to 86 million metric tonnes per year 
by 2040 , develop plastic-to-plastic conversion potentially to a global capacity of up to 13 million metric tonnes per year, securely dispose the $23 \%$ of plastic that still cannot be economically recycled, and lastly, reduce plastic waste exports into countries with low collection and high leakage rates by $90 \%$ by 2040 as shown in (Figure 7) [5]. Integrated system change achieves social, environmental, and economic benefits. In addition to the $80 \%$ reduction of plastic leakage into the ocean by 2040, governments across the world would save US\$70B over 20 years relative to BAU, 700,000 jobs created by 2040 relative to BAU, $25 \%$ reduction in annual GHG emissions by 2040 relative to BAU, 55\% reduction in virgin plastic demand by 2040 relative to BAU, 195 million metric tonnes reduction in other environmental leakage (land and atmosphere) [5]. Plastic polymers should be used completely since they are technologically $100 \%$ recyclable.

Some of them have the perfect cradle-to-cradle lifecycle as they can be used again and again to produce similar goods. Some can also be reused just as they are by shredding the plastic object into flakes, melting it and reusing [62].

\section{Conclusion}

Hope is not completely lost as the plastic pollution challenge can be substantially controlled within a generation's time. But, are we ready to act? All hands must be on deck as the COVID-19 crisis is highlighting the need for cooperative action, now is the moment to make that change. Governments on their own part must recognize the crucial role of waste management services and enact necessary policies for the transition to a sustainable future. Such efforts would advance multiple Sustainable Development Goals including SDG 11, SDG12 and SDG14 which calls for cities to ensure effective waste management; reduce waste management through prevention, reduction, recycling and reuse; reduce marine pollution of all kinds respectively. But the governments cannot always do it alone. Companies all along the plastic value chain from manufacturers to retailers are expected to show their commitment towards public health by accelerating efforts to end plastic waste as everyone bold enough to step up to the challenge of environmental stewardship by contributing to the creation of a circular economy will reap a rich bounty of public trust and profitability in the future.

As the global economy finds a new pathway with respect to the COVID-19 pandemic, aid agencies, development banks and NGOs should invest in building effective waste management systems. Beyond helping to keep plastic waste out of our oceans, such systems can provide decent jobs and improved livelihoods, resulting in stronger and more sustainable economies in the long term. It is a fact that the warning bells of plastic waste have been ringing loud and clear for years, the last thing the world needs is to allow well-known threats like this to remain unaddressed. There are insufficiently available, accurate and internationally compactible solid waste data. It is therefore an immense task to establish a comprehensive data baseline estimate of sources, stocks and flows of plastic pollution. Let each and every one of us act now or else face the salient consequences in the near future. More funds should be made available to the trans-Atlantic research team to further re-engineer the two superenzymes, PETase and MHETase so as to bring a logical end to plastic waste within the shortest possible time.

\section{References}

1. Galaverni M, Bologna G, Danovaro R (2020) The Loss of Nature and The Rise of Pandemics: Protecting human and planetary health. WWF International Avenue du Mont-Blanc 1196 Gland, Switzerland, p. 21.

2. Hodges K, Jackson J (2020) Pandemic and the global environment. Science Advances 6(28): eabd1325.

3. Adyel TM (2020) Accumulation of plastic waste during COVID-19. Science 369(6509): 1314-1315.

4. Pabortsava K, Lampitt R (2020) High concentrations of plastic hidden beneath the surface of the Atlantic Ocean. Nature Communications 11: 4073.

5. Stuchtey MR, Dillon T (2020) Breaking the Plastic Wave: A Comprehensive Assessment of Pathways towards Stopping Ocean Plastic Pollution. The Pew Charitable Trust, p. 5.

6. Borrelle SB, Ringma J, Law KL (2020) Predicted growth in plastic waste exceeds efforts to mitigate plastic pollution. Science 369(6510): 15151518.

7. Bank MS, Hansson SV (2019) The plastic cycle: A novel and holistic paradigm for the Anthropocene. Environ Sci Technol 53: 7177.

8. Kane IA, Clare MA, Miramontes E, Wogelius R, Rothwell JJ, et al. (2020) Seafloor microplastic hotspots controlled by deep-sea circulation. Science 368: 1140.

9. Velis C, Cook E (2020) How Earth's plastic pollution problem could look by 2040. The Conversation. (Accessed August 26, 2020).

10. The Economist (2018) The known unknowns of plastic pollution. (Accessed September 18, 2020).

11. Nott G (2020) Can the sustainable packaging effort survive COVID-19? The Grocer. (Accessed August 24, 2020).

12. Li Q Guan X, Wu P, Wang X, Zhou L (2020) Early Transmission Dynamics in Wuhan, China, of Novel Coronavirus-Infected Pneumonia. New England Journal of Medicine 382(13): 1199- 1207.

13.Zhu N, Zhang D, Wang W, Li X, Yang B, et al. (2020) Novel Coronavirus from Patients with Pneumonia in China, 2019. China Novel Coronavirus Investigating and Research Team. New England Journal of Medicine 382: 727-733.

14. Duer J (2020) The plastic pandemic is only getting worse during COVID-19. World Economic Forum. (Accessed August 24, 2020).

15. Way C (2020) Healthcare is still hooked on single use plastic PPE but there are more sustainable options. The Conversation. (Accessed September 21, 2020).

16. Brownlee A (2020) Muskoka residential waste- and green bin use- on the rise in COVID-19 era. (Accessed on September 22, 2020).

17. Bell D (2020) Massive trash 'tsunami' invades Honduras beaches. Sport Grind Entertainment. (Accessed September 22, 2020).

18. Break Free from Plastic (2019) Global Brand Audit Report. (Accessed August 24, 2020).

19. Chalabi M (2019) Coca-Cola is world's biggest plastic polluter-again. The Guardian ISSN 0261-3077.

20. United Nations Environment Programme UNEP (2018) Single-use plastics: A roadmap for sustainability. Unenvironment org Rev 1: 1-15.

21. Sharma KD, Jain S (2020) Municipal solid waste generation, composition, and management: The global scenario. Social Responsibility Journal 16(6): 917-948.

22. Market Watch (2020) Plastic Waste Management Market CoVID-19 Impact Analysis with Global Countries Data, 2020 Global Share Analysis, Business Growth. (Accessed September 22, 2020). 
23. Bhatti M, Akram H, Basit HM, Khan AU, Mahwish S, et al. (2020) E-commerce trends during COVID-19 pandemic. International Journal of Future Generation Communication and Networking 13(2): 1449-1452.

24. PRNewswire (2020) COVID-19 impact on packaging market by material type, application, and region-global forecast to 2021. Business Insider. (Accessed September 19, 2020).

25. Feber D, Lingqvist O, Nordigarden D (2020) How the packaging industry can navigate the pandemic. Mckinsey \& Company. (Accessed August 26, 2020).

26. Trotter C (2020) Packaging and COVID-19: What's happening? European Brand and Packaging Design Association EPDA. (Accessed August 24, 2020).

27. Newburger E, Lucas A (2020) Plastic waste surges as coronavirus prompts restaurants to use more disposable packaging. CNBC. (Accessed August 24, 2020).

28. Morrison 0 (2020) Plastic Packaging: Hero or Villain in the coronavirus era? Food Navigator. (Accessed August 24, 2020).

29. Bir B (2020) Health or Environment: plastic dilemma over COVID-19. AA. (Accessed August 22, 2020).

30. Staub C (2020) COVID-19 damages supply chain for deposit materials. Resource Recycling. (Accessed August 24, 2020).

31. Poole J (2020) Terracycle revs up disposable glove and mask recycling with automaker partnership. Packaging Insight. (Accessed August 26, 2020).

32. Bengali S (2020) The COVID-19 pandemic is unleashing a tidal wave of plastic waste. The Los Angeles Times. (Accessed September 21, 2020).

33. Boyle L (2020) How do we tackle the rising tide of pandemic-driven plastic waste? Independent. (Accessed September 22, 2020).

34. Kolata G (2020) As Coronavirus Looms, Mask Shortage Gives Rise to Promising Approach. New York Times. (Accessed September 21, 2020).

35. Heiges J, O’Neil K (2020) COVID-19 has resurrected single-use plastics, are they back to stay? The Conversation. (Accessed August 24, 2020).

36. Heller MC, Mazor MH, Koeleian GA (2020) Plastics in the US: Toward a material flow characterization of production markets and end of life. Environmental Research Letters 15(09): 4034

37. Konyn C (2020) Another side effect of COVID-19: The sure in plastic pollution. Earth org. (Accessed September 21, 2020).

38. Statista (2020) Share of people who plan to increase their use of food delivery services due to the coronavirus (COVID-19) pandemic in Great Britain in March 2020. Statista.

39. Klemes JJ, Fan YV, Tan RR, Jiang P (2020) Minimising the present and future plastic waste, energy and environmental footprints related to COVID-19. Renewable and Sustainable Energy Reviews 127: 109883.

40. Smith L (2020) Plastic Waste. House of Commons Library.

41. Lewis M (2020) The fight to ban single-use plastics has been set back years by the pandemic - but innovative new products are coming to the rescue. The Star. (Accessed September 22, 2020).

42. Cheng G (2020) The environmental impacts of COVID-19: A closer look. Nature \& Conservation/Asia Wide.

43. Schlosberg J, Zee G, Ebbs S, Griswold L (2020) COVID-19 pandemic

ISSN: 2574-1241

DOI: 10.26717/BJSTR.2021.33.005437

Ombugadu A. Biomed J Sci \& Tech Res

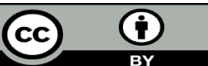

This work is licensed under Creative

Commons Attribution 4.0 License

Submission Link: https://biomedres.us/submit-manuscript.php causes concern over plastic pollution: Environmental headlines you missed this week. ABC News.

44. Reimonn G, Lu T, Gandhi N, Chen W (2019) Review of Microplastic Pollution in the Environment and Emerging Recycling Solutions. Journal of Renewable Materials 7(12): 1251-1268.

45. Free CM, Jensen OP, Mason SA, Eriksen M, Williamson NJ, et al. (2014) High-levels of microplastic pollution in a large, remote, mountain lake. Marine Pollution Bulletin 85(1): 156-163.

46. Desforges JPW, Galbraith M, Ross PS (2015) Ingestion of microplastics by zooplankton in the northeast Pacific Ocean. Archives of Environmental Contamination and Toxicolology 69(3): 320-330.

47. Gil Delgado JA, Guijarro D, Gosálvez RU, López Iborra GM, Ponz A, et al. (2017) Presence of plastic particles in waterbirds faeces collected in Spanish lakes. Environmental Pollution 220: 732-736.

48. Yu Y, Zhou D, Li Z, Zhu C (2018) Advancement and challenges of microplastic pollution in the aquatic environment: A review. Water, Air \& Soil Pollution 229(5): 140.

49. Fleming S (2019) This 12-year-old built an underwater robot to fight plastic pollution. World Economic Forum.

50. American Chemical Society (2020) Microplastics in humans. ACS.

51. Koelmans AA, Besseling E, Shim WJ (2015) Nanoplastics in the aquatic environment Critical review. Marine Anthropogenic Litter p. 9-14.

52. Newburger E (2020) Toxic microplastics hotspots are accumulating on the ocean floor in record levels. CNBC.

53. Jambeck JR, Geyer R, Wilco C, Siegler TR, Perryman M, et al. (2015) Plastic waste inputs from land into the ocean. Science 347(6223): 768771.

54. Guo X, Sun X, Chen Y, Hou L, Liu M, et al. (2020) Antibiotic resistance genes in biofilms on plastic wastes in an estuarine environment. Science of the Total Environment 745: 140916.

55. Yang Y, Liu W, Zhang Z, Grossart H, Gadd GM (2020) Microplastics provide new microbial niches in aquatic environments. Applied Microbiology and Biotechnology 104: 6501-6511.

56. Bank MS, Ok YS, Swarzenski PW (2020) Microplastic's role in antibiotic resistance. Science 369(6509): 1315.

57. Greenjoy (2020) Greenjoy Straw: Living the green dream. (Accessed September 25, 2020).

58. Greenpeace Africa (2020) 34 plastic bans in Africa: A reality check. Greenpeace. (Accessed August 26, 2020).

59. Hahladakis JN, Iacovidou E (2019) An overview of the challenges and trade-offs in closing the loop of post-consumer plastic waste (PWPC): Focus on recycling. Journal of Hazardous Materials 380: 120887.

60. Knott BC, Erickson E, Allen MD, Gado JE, Graham R, et al. (2020) Characterization and engineering of a two-enzyme system for plastics depolymerization. Proceedings of the National Academy of Sciences of the United States of America 17(41): 25476-25485.

61. Lau WY, Shiran Y, Bailey RM, Cook E, Velis CA, et al. (2020) Evaluating scenarios toward zero plastic pollution. Science 369(6510): 1455-1461.

62. Cestari S (2020) Plastics could help build a sustainable future-here's how. The Conversation. (Accessed September 21, 2020).

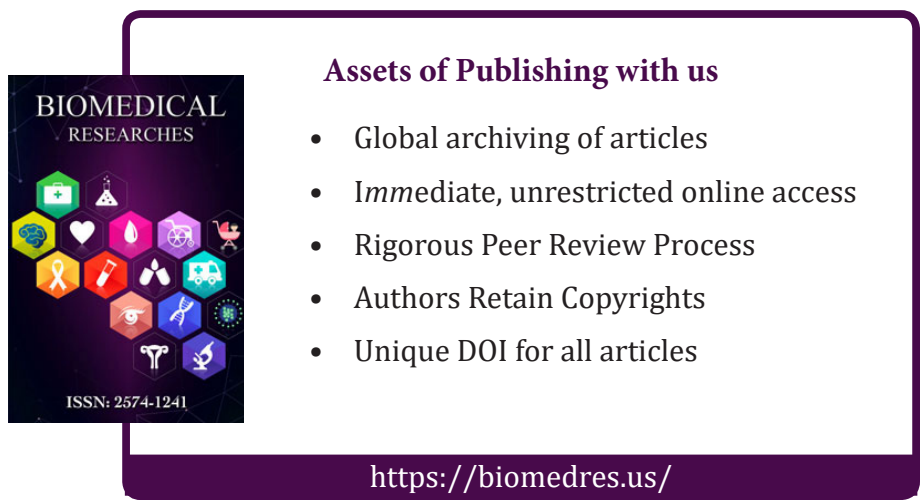

